\title{
Change in malate dehydrogenase and alpha amylase activities in Rubus fruticosus and Valeriana jatamansi treated granary weevil, Sitophilus granarius
}

\author{
S. Ahmed * (D), A. Zia ${ }^{b}$ (D), S. A. Mehmood (D), W. A. Panhwar $^{c}$ (D), W. Khan (D), M. Shah $^{e}$ \\ and Irfan Ullah ${ }^{f}$
}

\author{
aDepartment of Zoology, Hazara University, Mansehra, Pakistan \\ ${ }^{b}$ National Insect Museum, National Agricultural Research Centre - NARC, Islamabad, Pakistan \\ 'Department of Zoology, Shah Abdul Latif University, Khairpur Mirs, Pakistan \\ ${ }^{\mathrm{d}}$ Department of Zoology, University of Malakand, Chakdara, Dir Lower, Pakistan \\ ${ }^{\mathrm{e} C e n t r e}$ for Animal Sciences \& Fisheries, University of Swat, Swat, Pakistan \\ ${ }_{\mathrm{f}}^{\mathrm{f}}$ Department of Biological Science, Karakoram International University, Gilgit Baltistan, Pakistan \\ *e-mail: shabirsaki@gmail.com
}

Received: August 16, 2019 - Accepted: November 27, 2019 - Distributed: May 31, 2021

(With 1 figure)

\begin{abstract}
Poor storage conditions provide favorable environment to stored grain pests for their growth. The bio-pesticides are the best alternatives to synthetic pesticides. Present study was conducted to compare toxicity of Rubus fruticosus and Valeriana jatamansi against granary weevil, Sitophilus granarius and subsequent changes in enzyme activity responsible for grain damage. In current research $5 \mathrm{~g}$ of $R$. fruticosus fruit and $V$. jatamansi rhizome powders were tested separately against $S$. granarius, in $50 \mathrm{~g}$ wheat whole grains for seven days in comparison with the control. The enzymatic activity of malate dehydrogenase and $\alpha$-amylase was observed in the cellular extracts of $S$. granarius. The insects were crushed and homogenized in phosphate-buffer solution and centrifuged at $10000 \mathrm{rpm}$ for 5 minutes. For the enzymatic measurement supernatant was tested; the spectrophotometer was adjusted at $340 \mathrm{~nm}$. The reagents were mixed and incubated at $25^{\circ} \mathrm{C}$ for five minutes. The cuvettes were placed in the experimental and reference sites of spectrophotometer and recorded the change in absorbance for 3-4 minutes. There was $5.60 \%$ and $14.92 \%$ reduction in the activity of malate dehydrogenase in $R$. fruticosus and $V$. jatamansi, treated insects, respectively. The alpha amylase enzyme activity was $6.82 \%$ reduced and $63.63 \%$ increase in $R$. fruticosus and $V$.jatamansi, treated insects, respectively. Present study addresses that both plant powders are effective against granary weevil by altering enzyme activities so both the plant powders can be used as bio-pesticides against the stored grains pests.
\end{abstract}

Keywords: granary weevil, pests, biopesticides, malate dehydrogenase, $\alpha$-amylase.

\section{Mudança nas atividades de malato desidrogenase e alfa amilase em Rubus fruticosus e gorgulho tratado com Valeriana jatamansi, Sitophilus granarius}

\section{Resumo}

As más condições de armazenamento proporcionam um ambiente favorável às pragas armazenadas para o crescimento. Os biopesticidas são as melhores alternativas aos pesticidas sintéticos. O presente estudo foi conduzido para comparar a toxicidade de Rubus fruticosus e Valeriana jatamansi contra gorgulhos, Sitophilus granarius e subsequentes alterações na atividade enzimática responsáveis por danos aos grãos. Na pesquisa atual, $5 \mathrm{~g}$ de frutos de $R$. fruticosus e pós de rizoma de $V$. jatamansi foram testados separadamente contra $S$. granarius, em $50 \mathrm{~g}$ de grãos integrais de trigo por sete dias, em comparação com o controle. A atividade enzimática da malato desidrogenase e $\alpha$-amilase foi observada nos extratos celulares de $S$. granarius. Os insetos foram esmagados e homogeneizados em solução tampão fosfato e centrifugados a $10000 \mathrm{rpm}$ por 5 minutos. Para a medição enzimática, o sobrenadante foi testado; o espectrofotômetro foi ajustado a $340 \mathrm{~nm}$. Os reagentes foram misturados e incubados a $25^{\circ} \mathrm{C}$ por cinco minutos. As cubetas foram colocadas nos locais experimentais e de referência do espectrofotômetro e registradas as alterações na absorbância por 3-4 minutos. Houve redução de 5,60\% e 14,92\% na atividade da malato desidrogenase em $R$. fruticosus e $V$. jatamansi, insetos tratados, respectivamente. A atividade da enzima alfa amilase foi reduzida em 6,82\% e aumento de 63,63\% em $R$. fruticosus e $V$. jatamansi, insetos tratados, respectivamente. O presente estudo aborda que ambos os pós de plantas são eficazes contra o gorgulho do celeiro, alterando as atividades enzimáticas, de modo que ambos os pós de plantas possam ser usados como biopesticidas contra pragas de grãos armazenados.

Palavras-chave: gorgulho, pragas, biopesticidas, malato desidrogenase, $\alpha$-amilase. 


\section{Introduction}

Cereals are main source of human diet with production exceeding 2100 million tons annually (Shewry, 2007). Bulk of harvested crop $(50 \%)$ is lost during storage (Fornal et al., 2007). The poor storage conditions provide favorable environment for the growth of stored grain pests (Stoll, 2000). Insect pests of cereals are responsible for reduction in quantity and quality of food grains (Udo, 2011). The weight losses in stored products are mainly associated with activities of insect pests (Arlian, 2002). According to an estimate, annual yield losses due to insect pest are 20-40 percent in overall agricultural products (FAO, 2018). About 1000 insect pests have been reported in harvested products worldwide (Atwal and Dhaliwal, 2008). Many strategies have been adopted to preserve cereals from pest infestations; including pesticides, bio pesticides, repellants, fumigants and biological control measures (Germinara et al., 2008).

Synthetic insecticides are widely used against insect pests (Tapondjou et al., 2005). These pesticides cause environmental pollution and develop resistant insect pests and high mammalian toxicity (Al-Moajel, 2000). Development of bio-insecticides has been an alternative strategy to use of synthetic pesticides (Hashim and Devi, 2003; Meena et al., 2006). In Asia a number of plant products have been traditionally used for protection of stored cereals (Isman, 2000). Plants derivative pesticides are renewable, biodegradable and have low mammalian cytotoxicity (Isman, 2008). Digestive enzymes convert complex biomolecules to simplest one (Erturk, 2006). Any disturbance in enzyme activity of insects is fatal for their survival (Shekari et al., 2008). Dehydrogenases are important tools for the investigation of insect metabolic activities during the course of development (Dickinson and Sullivan, 1975). Terra and Ferreira (2005) confirmed that Amylases are obligatory to digest carbohydrates in insects.

\section{Material and Methods}

\subsection{Sampling area}

The infested wheat grains with $S$. granarius were randomly collected from wheat stores of Mansehra and reared in the laboratory. Local wheat, Triticum aestivum was used for rearing of insect. The wheat used in the experiment was cleaned from insects by fumigation with Aluminum sulphate. Fresh, mature and unripen fruits of $R$. fruticosus were collected from Shatey, Mansehra. The rhizomes of $V$. jatamansi were collected from Kund Bangla, Mansehra, Pakistan (Figure 1).

\subsection{Rearing of insects}

Three hundred adult $S$. granarius were grown in 2-liter jar $(14 \times 13.6 \mathrm{~cm})$ having $750 \mathrm{~g}$ purified wheat grains at a controlled temperature of $37 \pm 2{ }^{\circ} \mathrm{C}$ and relative-humidity $60 \pm 10 \%$ (Mehmood, 2007). Each rearing jar was covered with muslin cloth for aeration.

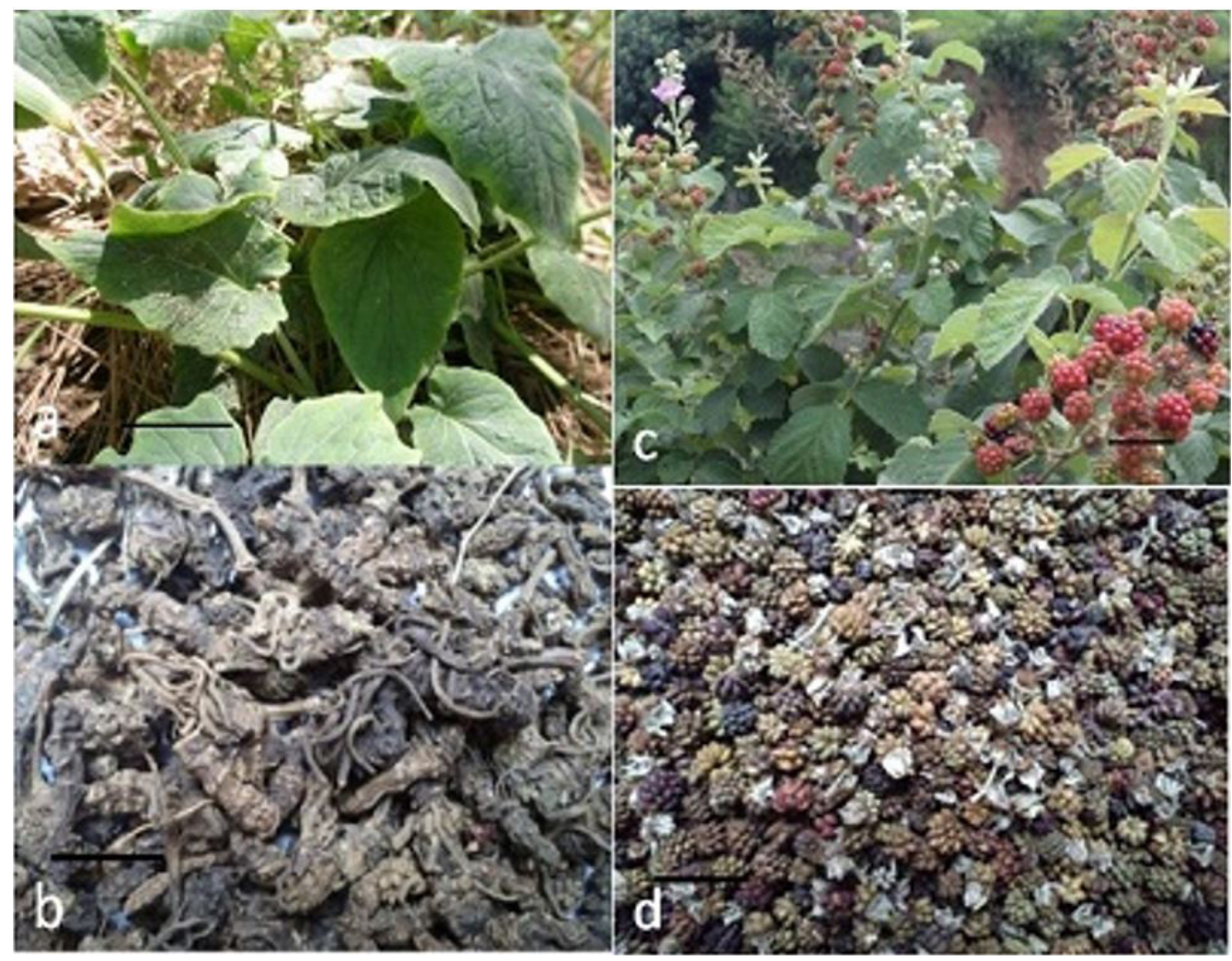

Figure 1. (a) Plant of V.jatamansi; (b) dried rhizome of V.jatamansi; (c) Plant of R. fruticosus; (d) dried fruits of R. fruticosus. 


\subsection{Preparation of plant powders}

Mature and unripened fruits of $R$. fruticosus and rhizome of $V$. jatamansi were collected, rinsed with distilled water and air dried in the laboratory at room temperature of $20^{\circ} \mathrm{C}$. Dried plant materials were grounded by electrical blender (Rehman et al., 2009). The resulting powders were sieved, using 40 mesh screens and stored in cool and dry place to maintain efficacy.

\subsection{Determination of malate dehydrogenase activity}

The enzymatic activity of malate dehydrogenase (MDH) was observed in the cellular extract of $S$. granarius after treatment with $R$. fruticosus and $V$. jatamansi powders and compared with control. The experimental insects were crushed and homogenized in phosphate buffer $(\mathrm{pH} 7.0)$ solution using a mortar and pistol. Homogenates were centrifuged (Force 1624 microcentrifuge, Edison, NJ, USA) at $10000 \mathrm{rpm}$ for 5 minutes. For the enzymatic measurement of malate dehydrogenase, supernatant was tested in spectrophotometer adjusted at $340 \mathrm{~nm}$. The following solutions were added into the cuvette (1.4 mL Phosphate buffer (0.1M), 0.04 mLCis-Oxaloacetic acid $(0.006 \mathrm{M})$ and $0.02 \mathrm{mLNADH}(0.00375 \mathrm{M})$. The reagents were mixed and incubated at $25{ }^{\circ} \mathrm{C}$ for five minutes. The cuvettes were placed in the experimental reference sites of spectrophotometer (Perkin Elmer lambd 25 UV/Visible, double-beam, Spectrophotometer, USA) for 2-3 minutes to achieve temperature equilibration, and pippeted $0.005 \mathrm{~mL}$ extract of insects into experimental cuvette, mixed it well and monitored the reaction for 2-3 minutes. The oxaloacetate and NADH is converted into L-Malate and NAD ${ }^{+}$by the enzymatic action of Malate dehydrogenase:

$\mathrm{MDH}$

Oxaloacetate $+\mathrm{NADH} \rightarrow$ L-Malate $+\mathrm{NAD}^{+}$

The measurement of MDH activity was based on the rate of decline in the absorbance at wave length $(\lambda)$ of $340 \mathrm{~nm}$, subsequent to the oxidation of NADH. One enzyme unit is defined as the amount of enzyme which can catalyze the conversion of one $\mu$ mole of oxaloacetate to malate per minute at $25^{\circ} \mathrm{C}$. The number of enzyme units per $\mathrm{mL}$ of cellular extract was calculated by using the Formula 1:

Enzyme activity $(U / m L)=\frac{\text { Absorbance change } \times \text { Total volume }(m L) \times D F}{6.22 \times \text { Enzyme volume }(\mathrm{mL})}$
Whereas: $\mathrm{DF}=$ Dilution factor of enzyme; $6.22=$ Extinction coefficient of NADH at $340 \mathrm{~nm}$ in milli moles (Worthington and Worthington, 2011).

\subsection{Determination of alpha amylase activity}

Enzymes dilutions were prepared using Sodium Phosphate $\left(\mathrm{Na}_{3} \mathrm{PO}_{4}\right) 0.02 \mathrm{M}$ buffers at $6.9 \mathrm{pH}$ for each strain separately in eppendorf tubes and kept in ice box. One gram of dinitosalicylic acid as color reagent was mixed in $20 \mathrm{~mL}$ of $2 \mathrm{M}$ sodium hydroxide $(\mathrm{NaOH})$ and slowly added $30 \mathrm{~g}$ sodium potassium tartrate tetrahydrate and made final volume to $100 \mathrm{~mL}$. One percent starch was dissolved in Sodium phosphate buffer $(0.02 \mathrm{M})$ having $0.006 \mathrm{M}$ sodium chloride $(\mathrm{NaCl}) .500 \mu \mathrm{L}$ of $1 \%$ starch solution was mixed with $20 \mu \mathrm{L}$ of cellular extract in triplicates. One $\mathrm{ml}$ of the salicylic acid solution was added to each reaction mixture and boiled for five minutes. The reacted samples were cooled to room temperature and added $10 \mu \mathrm{L}$ of distilled to each tube (making 6.66 time dilution). The absorbance of diluted reaction mixture was measured at $540 \mathrm{~nm}$ and compared with standard curve of maltose for the determination of $\mu$-moles of maltose liberated in the reaction. A unit of amylase is defined as the amount of enzyme which can liberate one $\mu$-moles of maltose from starch in one minute (Worthington and Worthington, 2011). The activity of enzyme was calculated as follows (Formula 2):

Enzyme activity $(U / m L)=\frac{\mu \text { moles of maltose liberated per minute }}{\text { Volume of enzyme added }(\mathrm{mL})}$

\section{Results}

The reduction in malate dehydrogenase activity for $R$. fruticosus and V.jatamansi against $S$. granarius revealed a decrease in the levels of enzyme by $5.60 \%$ and $14.92 \%$ respectively, compared with that of control (Table 1).

The activity level of amylase in the extract of $R$. fruticosus and $V$. jatamansi treated insects showed $6.82 \%$ decrease and $63.63 \%$ increase respectively. The results represented a significant decrease in the $\alpha$-amylase activity in $V$.jatamansi treated insects while a modified activity was observed in $R$. fruticosus treated S. granarius (Table 2).

Table 1. Reduction in malate dehydrogenase activity for $R$. fruticosus and V. jatamansi against $S$. granarius.

\begin{tabular}{cccc}
\hline Treatments $\mathbf{( g )}$ & Units of Enzyme (MDH)* & $\mathbf{\%}$ & Change in enzyme activity \\
\hline Control & 9.1274 & 100 & \\
R. fruticosus & 8.6166 & 94.40 & $5.60 \%$ decrease \\
V. jatamansi & 7.7648 & 85.08 & $14.92 \%$ decrease \\
\hline
\end{tabular}

*Unit of enzyme: amount of enzyme which can catalyze the conversion of one $\mu$ mole of oxaloacetate to malate per minute at $25{ }^{\circ} \mathrm{C}$.

Table 2. Alteration in alpha amylase activity for R. fruticosus and V. jatamansi against S.granarius.

\begin{tabular}{|c|c|c|c|}
\hline Treatments & Units of enzyme(amylase)* & $\% *$ & Change in enzyme activity \\
\hline Control & 7359 & 100 & - \\
\hline R. fruticosus & 6857 & 93.18 & $6.82 \%$ decrease \\
\hline$V$.jatamansi & 12042 & 36.37 & $63.63 \%$ increase \\
\hline
\end{tabular}

*One unit enzyme: amount of enzyme which can liberate one $\mu$ mole of maltose from starch in one minute. 


\section{Discussion}

This study was carried out from May-September, 2011 to assess the efficacy of two plant powders $R$. fruticosus and V.jatamansi against $S$. granarius and changes in the enzyme activities. Both the plant powders were collected from different localities of Mansehra Pakistan and were used as treatment against the granary weevil.

In the present study the malate dehydrogenase enzyme activity in $R$. fruticosus and $V$. jatamansi treated $S$. granarius was reduced by $5.60 \%$ and $14.92 \%$ respectively, compared with that of control. In the previous studies of Hamadah et al. (2010) the alterations in the dehydrogenase activity of the desert locust Schistocerca gregaria was observed, the wild plant Fagonia bruguieri changed the enzyme activity $+0.5 \%$ in the early-aged nymphs at the lower concentration level of petroleum ether extract along the nymphal instar but the strongest enhancing effect was exhibited in the mid-aged nymphs.

In the present study the $\alpha$-amylase enzyme activity in $R$. fruticosus and $V$. jatamansi treated $S$. granarius $6.82 \%$ decrease and $63.63 \%$ increase respectively. Earlier Nehad et al. (2008) reported that activity of amylase was decreased after $24 \mathrm{~h}$ of plant extract treatment. Mehrabadi et al. (2011) reported Inhibitory effect of plants extracts of $A$. Siberia, P. harmala, and $T$. vulgaris against C. maculatus showed the reduced amylase activity $19.22 \%$, $4.58 \%$, and $7.22 \%$ respectively. Ahmad et al. (2019) used different plant powders against $T$. castaneum infesting stored grains. Allium sativum and Zingeber officinale were more effective resulting into 15 time's higher adult mortality. The Azadirachta indica seed powder against the beetle showed better control at lowest $(1 \% \mathrm{w} / \mathrm{w})$ and the highest doses $(5 \% \mathrm{w} / \mathrm{w})$.

\section{Acknowledgements}

Dr. Muhammad Shahid Nadeem is appreciated to accomplish my enzyme assay on the bio-pesticides, treated insects.

\section{References}

AHMAD, F., IQBAL, N., ZAKA, S.M., QURESHI, M.K., SAEED, Q., KHAN, K.A., GHRAMH, H.A., ANSARI, M.J., JALEEL, W., AASIM, M. and AWAR, M.B., 2019. Comparative insecticidal activity of different plant materials from six common plant species against Tribolium castaneum (Herbst) (Coleoptera:Tenebrionidae). Saudi Journal of Biological Sciences, vol. 26, no. 7, pp. 1804-1808. http://dx.doi.org/10.1016/j.sjbs.2018.02.018. PMid:31762662.

AL-MOAJEL, N.H., 2000. Turnip seed (Brassica napus) extracts as grain wheat protectants against the grainary weevil, Sitopltilus granarius L. Saudi Journal of Biological Sciences, vol. 7, no. 1, pp. 94-102.

ARLIAN, L.G., 2002. Arthropod allergens and human health. Annual Review of Entomology, vol. 47, no. 1, pp. 395-433. http://dx.doi. org/10.1146/annurev.ento.47.091201.145224. PMid:11729080.

ATWAL, A.S. and DHALIWAL, G.S., 2008. Agricultural pests of South Asia and their management. New Delhi: Kalyani Publishers.
DICKINSON, W.J. and SULLIVAN, D.T., 1975. Gene enzyme system in Drosophila. Berlin: Springer.

ERTURK, O., 2006. Antifeedant and toxicity effects of some plant extracts on thaumeto poaesolitaria Frey. (Lepidoptera: thaumetapoeidae). Turkish Journal of Biology, vol. 30, pp. 51-57.

FOOD AND AGRICULTURE ORGANIZATION OF THE UNITED NATIONS - FAO, 2018 [viewed 15 Jan 2012]. Codexalimentarius [online]. Rome: FAO. Available from: https://www.fao.org/faowho-codexalimentarius/en/Pesticides

FORNAL, J., JELIŃSKI, T., SADOWSKA, J., GRUNDAS, S., NAWROT, J., NIEWIADA, A., WARCHALEWSKI, J.R. and BŁASZCZAK, W., 2007. Detection of grainer yweevil Sitophilus granarius L., eggs and internal stage analysis. Journal of Stored Products Research, vol. 43, no. 2, pp. 142-148. http://dx.doi. org/10.1016/j.jspr.2006.02.003.

GERMINARA, G.S., CRISTOFARO, A. and ROTUNDO, G., 2008. Behavioral responses of adult Sitophilus granarius to individual cereals volatiles. Journal of Chemical Ecology, vol. 34, no. 4, pp. 523-529. http://dx.doi.org/10.1007/s10886-0089454-y. PMid:18340486.

HAMADAH, K.S., BASIOUNY, A.L. and GHONEIM, K.S., 2010. Alterations in the lactate dehydrogenase activity of the desert locust $S$. gregaria by the wild plant Fagonia bruguieri (Zygophyllaceae). Academic. The Journal of Biological Sciences, vol. 3, no. 2, pp. 1-9.

HASHIM, M.S. and DEVI, K.S., 2003. Insecticidal action of the polyphenolic rich fractions from the stem bark of Streblusasperon Dysdercuscingulalus. Fitoterapia, vol. 74, no. 7-8, pp. 670-676. http://dx.doi.org/10.1016/S0367-326X(03)00186-2. PMid:14630171.

ISMAN, M.B., 2000. Plant essential oils for pest and disease management. Crop Protection, vol. 19, no. 8-10, pp. 603-608. http://dx.doi.org/10.1016/S0261-2194(00)00079-X.

ISMAN, M.B., 2008. Botanical insecticides: for richer, for poorer. Pest Management Science, vol. 64, no. 1, pp. 8-11. http://dx.doi. org/10.1002/ps.1470. PMid:18022796.

MEENA, R., SUHAG, P. and PRATES, H.T., 2006. Evaluation of ethanolic extract of Baccharisgenistelloides against stored grain pests. Journal of Stored Products Research, vol. 34, no. 4, pp. 243-249.

MEHMOOD, T., 2007. Toxicity and effect of crude plant extract, Solanum Surrattence on red flour beetle, Tribolium castanium. Kohat, Pakistan: Department of Zoology, Kohat University of Science and Technology. M. Sc Thesis in Zoology.

MEHRABADI, M., BANDANI, A.R., SAADATI, F. and MAHMUDVAND, M., 2011. $\alpha$ amylase activity of stored products insects and its inhibition by medicinal plant extracts. Journal of Agricultural Science and Technology, vol. 13, pp. 1173-1182.

NEHAD, M.E., HUSSAIN, F.D. and YASSER, A.E., 2008. Toxicological evaluation and biochemical impacts for radient as a new generation of spinosyn on spodopteralittoralis (Boisd.) larvae. Egyyptin Academy Journal of Biological Sciences, vol. 2, pp. 85-97.

REHMAN, J., JILLANI, G., KHAN, M., MASIH, R. and KANVIL, S., 2009. Repellent and oviposition detterent effects of indigenous plant extracts to peach fruit fly, Bactrocera zonata Saunders (Diptera: tephritidae). Pakistan Journal of Zoology, vol. 41, pp. 101-108. 
SHEKARI, M., SENDI, J.J., ETEBARI, K., ZIBAEE, A. and SHADPARVAR, A., 2008. Effects of Artemisia annua L. (Asteracea) on nutritional physiology and enzyme activities of elm leaf beetle, Xantho galerucaluteola Mull (Coleoptera: chrysomellidae). Pesticide Biochemistry and Physiology, vol. 91, no. 1, pp. 66-74. http://dx.doi.org/10.1016/j.pestbp.2008.01.003.

SHEWRY, P.R., 2007. Improving the protein content and composition of cereal grain. Journal of Cereal Science, vol. 46, no. 3, pp. 239-250. http://dx.doi.org/10.1016/j.jcs.2007.06.006.

STOLL, G., 2000. Natural crop protection in the tropics, letting information comes on life: Agrecol/CTA. 2nd ed. Weikersheim: Magraf, pp. 23-89.

TAPONDJOU, A.L., ADLER, C., FONTEM, D.A., BOUDA, H. and REICHMUTH, C., 2005. Bioactivities of cymol and essential oils of Cupressussem pervirens and Eucalyptus saligna against
Sitophilus zeamais Motschulsky and Tribolium confusum du Val. Journal of Stored Products Research, vol. 41, no. 1, pp. 91-102. http://dx.doi.org/10.1016/j.jspr.2004.01.004.

TERRA, W.R. and FERREIRA, C., 2005. Biochemistry of digestion. In: L.I. GILBERT, ed. Comprehensive molecular insect science. Amsterdam: Elsevier, pp. 171-224. http://dx.doi. org/10.1016/B0-44-451924-6/00053-3.

UDO, I.O., 2011. Potentials of Zanthoxylum xanthoxyloides (LAM.) for the control of stored product insect pests. Journal of Stored Products and Postharvest Research, vol. 2, no. 3, pp. 40-44.

WORTHINGTON, K. and WORTHINGTON, V., 2011 [viewed 15 Jan 2012]. Worthington enzyme manual [online]. Lakewood, NJ: Worthington Biochemical Corporation. Available from: http:// www.worthington-biochem.com/pap/default.html 